\title{
Kepatuhan Pengobatan Diabetes Mellitus Tipe 2 Ditinjau Dari Karakteristik Penderita Di Desa Satrean Maron Probolinggo
}

\author{
Ana Fitria Nusantara ${ }^{1 *}$, Atik Setiawan Wahyuningsih ${ }^{2}$ \\ ${ }^{1}$ Prodi Sarjana Keperawatan, Stikes Hafshawati Pesantren Zainul Hasan Genggong Probolinggo \\ ${ }^{2}$ Prodi Pendidikan Ners Stikes Surya Mitra Husada Kediri \\ *Email: anafitriaachmad@gmail.com
}

\begin{abstract}
Kata Kunci
Diabetes

Mellitus,

Kepatuhan,

Karakteristik

Abstrak

Diabetes mellitus (DM) merupakan salah satu penyakit degeneratif kronis yang prevalensinya semakin meningkat setiap tahun.Seperti pada tahun 2025 diperkirakanmeningkat menjadi 333 juta sehingga penyakit DM di dunia mencapai 1,9\% dan telah menjadikan DM sebagai penyebab kematian urutan ke tujuh di dunia. Penelitian ini bertujuan mengidentifikasi kepatuhan pengobatan berdasarkan karakteristik penderita DMtipe 2 di Desa Satrean Maron Probolinggo.Desain penelitian ini adalah observasional dengan tehnik purposive sampling menggunakan alat ukur kuesioner.Data yang diperoleh dianalisa dengan distribusi frekuensi.Hasil penelitian yang dilakukan pada 30 pasien DM tipe 2, didapatkan databahwa sebagian besar penderita tidak patuh dengan karakteristik usia dewasa akhir 36,7\%, 60\%tidak bekerja, 76,7\%berpendidikan SD,dan 73,3\% perempuan.Sehingga dapat disimpulkan bahwa sebagian besar penderita DM yang tidak patuh dalam pengobatan adalah perempuan usia dewasa akhir yang tidak bekerja dengan tingkat pendidikan SD. Pendidikan kesehatan pada penderita dan keluarga penting untuk dilakukan. Pemahaman yang baik tentang penatalaksanaan DM dapat memperbaiki kepatuhan dalam pengobatan.
\end{abstract}

\section{Treatment Adherence of Type 2 Diabetes Mellitus reviewed from the Characteristics of Patients in Satrean Maron Probolinggo Village}

\begin{abstract}
Key Words:
Abstract

Diabetes

Diabetesmellitus (DM) is a chronic degenerative disease that the prevalence is

Mellitus,

Adherence, Characteristics increasing every year. In 2025, will increase to 333 million estimatly.so that DM in the world reaches $1.9 \%$ and has made DM became the seventh cause of death in the world. The aim at this study is to identify the treatment adherence based on the characteristics of type 2 DM patients in Satrean Maron Probolinggo Village. The design of this research was observational with purposive sampling technique using questionnaire as ainstrument. The data obtained was analyzed by frequency distribution. The results of research conducted on 30 patients with type 2 diabetes, obtained data that mostly non-adherent patients with characteristics below; late adult were $36.7 \%$, 60\% have no work, $76.7 \%$ had elementary education level, and $73.3 \%$ were women. So it can be concluded that the majority of DM patients who do not adhere to treatment are late adult women who do not work and only educated by elementary education level. Health education for sufferers and families are important. A good understanding of DM management can improve adherence of treatment.
\end{abstract}


PROFESI (Profesional Islam): Media Publikasi Penelitian

2019; Volume 16; No 2.

Website: ejournal.stikespku.ac.id

\section{PENDAHULUAN}

World Health Organisation (WHO) mendefinisikan bahwa diabetes melitus merupakan suatu penyakit yang ditandai dengan terjadinya hiperglikemia dan gangguan metabolisme karbohidrat, lemak, dan protein yang dihubungkan dengan kekurangan secara absolut atau relatif dari kerja dan atau sekresi insulin (WHO, 2006). Penderita Diabetes Mellitus setiap tahunnya terus mengalami peningkatan seperti pada tahun 2025 diperkirakan meningkat menjadi 333 juta. Selain itu, prevalensi pasien Diabetes Mellitus di dunia diprediksi mencapai 1,9\% dan menjadikan penyebab kematian urutan ke tujuh di dunia (American Medical Association, 2008).

Keberhasilan suatu pengobatan sangat dipengaruhi oleh diri individu itu sendiri, seperti pengetahuan terhadap penyakitnya dan kepatuhan menjalani pengobatannya. Kepatuhan merupakan istilah umum yang menggambarkan sejauhmana perilaku seseorang (minum obat, diet dan / atau melaksanakan perubahan gaya hidup) sesuai denganrekomendasi dari penyedia layanan kesehatan. WHO memperkirakan bahwa kepatuhan untuk terapi jangka panjang pada penyakit kronis adalah serendah 50\%di negara maju, dan jauh lebih rendah pada negara berkembang (Adikusuma et al., 2014).

Kepatuhan dalam pengobatan memegang peranan penting dalam mencapai target keberhasilan terapi, terutama untuk penyakit kronis seperti diabetes melitus. Rendahnya kepatuhan pasien terhadap pengobatan diabetes melitus merupakan salah satu penyebab rendahnya kontrol terhadap kadarglukosa darah.Seperti yang ditunjukkan pada hasil penelitian Ramadona (2011) menyebutkan bahwa kepatuhan penderita DM dalam melakukan terapi pengobatan secara teratur menjadi aspek utama yang sangat mempengaruhi tingkat kesembuhan pasien.

Penelitian yang dilakukan oleh Basuki (2009) menyatakan bahwa pasien yang menjalani pengobatan rawat jalan menunjukkan lebih dari $70 \%$ pasien tidak minum obat sesuai dengan dosis yang seharusnya karena pasien merasa bahwa tubuhnya sudah sehat sehingga pasien tidak berobat kembali. Rendahnya kepatuhan pasien ini menyebabkan kadar glukosa darah pada pasien sering kali naik dan cenderung tidak stabil.
Terdapat beberapa faktor yang mempengaruhi kepatuhan penderita DM terhadap pengobatan, diantaranya adalah faktor usia, jenis kelamin, pendidikan, sosial ekonomi, pengetahuan yang rendah serta depresi yang dialami oleh penderita (Davies et al., 2013).

Kondisi tersebut serupa dengan kondisi yang terjadi di desa Satrean.Sesuai dengan hasil studi pendahuluan yang telah dilakukan memperlihatkan bahwa pasien diabetes mellitus tipe II di Desa Satrean sebanyak 30 orang.Sekitar 10 dari 30 orang mampu menjelaskan mengenai pengobatan yang harus dilakukan pada pasien diabetes mellitus sedangkan sebaliknya pasien mengungkapkan bahwa kurang memahami dan tidak melakukan pengobatan secara tepat.

Sesuai dengan paparan permasalahan yang telah diuraikan diatas, maka penulis sangat tertarik untuk melakukan penelitian yang lebih mendalam mengenaigambaran kepatuhan pengobatan berdasarkan karakteristik pederita diabetes mellitus tipe 2 .

Tujuan penelitian ini adalah untuk memberikan gambaran distribusi karakterisik kepatuhan pengobatan berdasarkanusia, jenis kelamin, pekerjaan dan tingkat pendidikan penderita diabetes mellitus tipe 2 di Desa Satrean Kecamatan Maron Probolinggo.

\section{METODE PENELITIAN}

Desain penelitian ini adalah observasional dengan pendekatan survei.Variabel dalam penelitian ini adalah karakteristik kepatuhan pengobatan pasien diabetes mellitus di Desa Satrean Kecamatan Maron Probolinggo.Responden penelitian ini adalah Pasien DM tipe 2 di Desa Satrean, Kecamatan Maron, Kabupaten Probolinggo yang berjumlah 30 orang.Teknik sampling menggunakan purposive sampling.Pengumpulan data untuk mengetahui kepatuhan pengobatan dan karakteristik responden penelitian diukur menggunakan kuesioner.Setelah data didapatkan, kemudian dilakukan analisis data.

\section{HASIL DAN PEMBAHASAN}

Data kepatuhan pengobatan penderita DM tipe 2 ditinjau dari karakteristik responden. 
PROFESI (Profesional Islam): Media Publikasi Penelitian 2019; Volume 16; No 2.

Website: ejournal.stikespku.ac.id

Tabel 1. Distribusi FrekuensiKepatuhan Pengobatan Penderita Diabetes Melitus Tipe 2 Berdasarkan Usia

\begin{tabular}{lcccc}
\hline & & \multicolumn{3}{c}{ Kepatuhan } \\
& & & \\
& & Pengobatan & Total \\
& & Patuh & Tidak & \\
& & Patuh & \\
\hline \multirow{4}{*}{ Kategori } & Dewasa awal & 1 & 2 & 3 \\
usia & $3.3 \%$ & $6.7 \%$ & $10.0 \%$ \\
& & 3 & 8 & 11 \\
& Dewasa akhir & $10.0 \%$ & $26.7 \%$ & $36.7 \%$ \\
& & 5 & 4 & 9 \\
& Lansia awal & $16.7 \%$ & $13.3 \%$ & $30.0 \%$ \\
& & 3 & 4 & 7 \\
& Lansia akhir & $10.0 \%$ & $13.3 \%$ & $23.3 \%$ \\
& & 12 & 18 & 30 \\
& Total & $40.0 \%$ & $60.0 \%$ & $100.0 \%$ \\
\hline
\end{tabular}

Tabel 1 menjelaskan bahwa sebagian besar responden berada pada kategori usia dewasa akhir yaitu berjumlah $11(36,7 \%)$ orang dengan 8 $(26,7 \%)$ orang tidak patuh dan $3(10 \%)$ orang patuh.

Tabel 2. Distribusi Frekuensi Kepatuhan Pengobatan Penderita Diabetes Melitus Tipe 2 Berdasarkan Pekerjaan

\begin{tabular}{|c|c|c|c|c|}
\hline & & \multicolumn{2}{|c|}{$\begin{array}{l}\text { Kepatuhan } \\
\text { Pengobatan }\end{array}$} & \multirow{2}{*}{ Total } \\
\hline & & Patuh & $\begin{array}{l}\text { Tidak } \\
\text { patuh }\end{array}$ & \\
\hline \multirow{6}{*}{$\begin{array}{l}\text { Status } \\
\text { Pekerjaan }\end{array}$} & Tidak bekerja & 7 & 11 & 18 \\
\hline & & $23.3 \%$ & $36.7 \%$ & $60.0 \%$ \\
\hline & Swasta & 5 & 7 & 12 \\
\hline & & $16.7 \%$ & $23.3 \%$ & $40.0 \%$ \\
\hline & Tatol & 12 & 18 & 30 \\
\hline & Iotal & $40.0 \%$ & $60.0 \%$ & $100.0 \%$ \\
\hline
\end{tabular}

Tabel 2 menjelaskan bahwa sebagian besar responden tidak bekerja yang berjumlah 18 $(60 \%)$ orang dengan $11(36,7 \%)$ orang tidak patuh dan $7(23,3 \%)$ orang patuh.
Tabel 3 Distribusi Frekuensi Kepatuhan Pengobatan Penderita Diabetes Melitus Tipe 2 Berdasarkan Tingkat Pendidikan

\begin{tabular}{ccccc}
\hline & \multicolumn{4}{c}{ Kepatuhan } \\
& & Pengobatan & Total \\
& & Patuh & $\begin{array}{c}\text { Tidak } \\
\text { patuh }\end{array}$ \\
\hline & SD & 9 & 14 & 23 \\
Status & & $30.0 \%$ & $46.7 \%$ & $76.7 \%$ \\
Pendidikan & SMP & 3 & 1 & 4 \\
& & $10.0 \%$ & $3.3 \%$ & $13.3 \%$ \\
& SMA & 0 & 3 & 3 \\
& & $0 \%$ & $10.0 \%$ & $10.0 \%$ \\
Total & & 12 & 18 & 30 \\
& & $40.0 \%$ & $60.0 \%$ & $100.0 \%$ \\
\hline
\end{tabular}

Tabel 3 menjelaskan bahwa sebagian besar responden berpendidikan SD yaitu berjumlah 23 $(76,7 \%)$ orang dengan $14(46,7 \%)$ orang tidak patuh dan $9(30 \%)$ orang patuh.

Tabel 4. Distribusi Frekuensi Kepatuhan Pengobatan Pengobatan Penderita Diabetes Melitus Tipe 2 Berdasarkan Jenis Kelamin

\begin{tabular}{ccccc}
\hline & & \multicolumn{3}{c}{ Kepatuhan } \\
& & \multicolumn{3}{c}{ Pengobatan } \\
& Patuh & Tidak & Total \\
& & Patuh & \\
\hline \multirow{3}{*}{ Jenis } & Laki-laki & 3 & 5 & 8 \\
Kelamin & & $10.0 \%$ & $16.7 \%$ & $26.7 \%$ \\
& Perempuan & 9 & 13 & 22 \\
& & $30.0 \%$ & $43.3 \%$ & $73.3 \%$ \\
& & 12 & 18 & 30 \\
& Total & $40.0 \%$ & $60.0 \%$ & $100.0 \%$ \\
\hline
\end{tabular}

Tabel 4 menjelaskan bahwa sebagian besar responden adalah perempuan yakni berjumlah 22 $(73,3 \%)$ orang dengan $13(43,3 \%)$ orang tidak patuh dan $9(40 \%)$ orang patuh.

Hasil penelitian menunjukkan bahwa penderita DM denganusialansia berada pada kategori tidak patuh. Bertambahnya usia menjadikan individu semakin beresiko terhadap penyakit diabetes mellitus tipe 2, keadaan ini ditunjang dengan life style yang tidak baik.

Selainitu, berdasarkan hasil penelitian yang dilakukan oleh Pladevall (2014) menyatakan bahwa salah satu penyebab yang dapat menye- 
PROFESI (Profesional Islam): Media Publikasi Penelitian

2019; Volume 16; No 2.

Website: ejournal.stikespku.ac.id

babkan peningkatan seseorang untuk beresiko tidak menjalani pengobatan secara patuh yakni adanya kelemahan fisik dan keterbatasan kognitif. Pada pasien lansia yang menderita DM dapat menyebabkan mereka beresiko tidak patuh menjalani pengobatan sebab berhubungan dengan faktor kognitif yang dialaminya seiring dengan bertambahnya usia sehingga dapat membuat terjadinya penurunan daya ingat. Kondisi ini akan menyebabkan adanya kesulitan yang dialami terutama dalam hal konsumsi obat-obatan sehingga menyebabkan pasien lansia tersebut akan memiliki ketergantungan terhadap orang lain untuk menyiapkan obat yang akan dikonsumsi.

Terapi farmakologi sangat pentinguntuk pasien dengandiabetes mellitusjika merekaingin mencapaikontrol glikemikyang baik.pedoman yang dikeluarkan olehAmerican Diabetes AssociationdanInstitut Nasional untuk Kesehatan dan Clinical Excellence(NICE) menyatakan bahwa insulin adalah agen penurun glukosa paling efektif dan bahwa terapi insulin adalah komponen kunci dari manajemen diabetes yang efektif selama perjalanan penyakit (Davies et al., 2013).

Meskipun sudah terbukti kuat bahwa mencapai kontrol glikemik yang baik membantu mencegah terjadinya komplikasi mikrojangka panjang dan komplikasi makrovaskulerdiabetes, akan tetapi banyak penderita yang tidak mencapai kontrol tersebut.

Pernyataan tersebut sesuai dengan yang diungkapkan oleh Pratiwi dan Endang (2013) menguraikan bahwa agar tingkat kepatuhan yang dimiliki oleh penderita DM semakin meningkat maka sangat diperlukan adanya kerjasama yang dilakukan oleh antar anggota keluarga sehingga mampu memperkuat kepatuhan terhadap program-pogram medis menjadi lebih tinggi termasuk didalamnya adalah kepatuhan dalam menjalani pengobatan.

Adapun bentuk kepatuhan yang dilakukan ini dapat diobservasi melalui adanya perubahan perilaku yang dilakukan oleh penderita DM seperti membiasakan diri untuk makan tepat waktu agar tidak terjadi perubahan pada kadar glukosa darah. Sesuai dengan paparan tersebut, maka semakin menguatkan bahwa adanya dukungan yang diberikan oleh anggota keluarga merupakan faktor yang sangat penting dalam menjalankan program kepatuhan pengobatan. Keluarga memiliki peranan yang sangat penting sebab dapat mengurangi ketidakpedulian pasien dalam menghadapi penyakit dan ketidakpatuhan yang disebabkan oleh adanya stimulus dari eksternal (Niven, 2012).

Berdasarkan penelitian yang telah dilakukan oleh Primanda, Kritpracha, dan Thaniwattananon (2011) juga menegaskan bahwa ketidakpatuhan pengobatan yang dilakukan oleh penderita DM juga tidak sepenuhnya merupakan kelalaian dari pasien namun juga disebabkan oleh faktor dari anggota keluarga yang biasanya tidak menyukai diet yang mereka konsumsi. Rendahnya dukungan keluarga ternyata juga dapat memberikan dampak negatif bagi diri penderita DM yaitu menyebabkan depresi sehingga mereka cenderung untuk tidak mengikuti anjuran pengobatan yang telah dianjurkan oleh petugas kesehatan. Sehingga dari paparan tersebut, dapat dipahami bersama bahwa memang sangat diperlukan adanya dukungan dari seluruh pihak terutama internal pasien agar dapat mendorong tingkat keberhasilan pengobatan pasien.

Hasil penelitian menunjukkan bahwa mayoritas penderita DM yang tidak patuh adalah individu yang tidak bekerja, dalam hal ini adalah ibu rumah tangga.

Terdapat beberapa faktor yang berperan dalam aktifitas fisik penderita diabetes mellitus, diantaranya adalah penderita tidak memahami manfaat aktifitas fisik bagi kesehatan, usia lanjut dan keterbatasan fisik (Purba, 2008).

Hasil ini sesuai dengan penelitian yang dilakukan oleh Darmayanti dalam Purba (2008) yang menjelaskan bahwa derajat kepatuhan penderita diabetes mellitus beragam yang disebabkan oleh perilaku malas yang meningkatkan jumlah penderita DM dan meningkatnya kejadian komplikasi.

Usia penderita yang mayoritas adalah dewasa akhir menjadi alasan untuk tidak melakukan latihan fisik. Hal ini sesuai dengan hasil penelitian Delamater (2006) yang menyatakan bahwa penderita yang berusia lebih dari 25 tahun lebih memilih latihan fisik yang lebih sedikit mengeluarkan kalori.

Pemahaman tersebut juga dipengaruhi oleh faktor budaya di Indonesia yang mana sebagian besar masyarakatnya bertani.Bekerja keras di sawah dengan menggunakan kekuatan fisik dan alat seadanya dikategorikan termasuk kegiatan olah raga.Begitu pula halnya dengan pekerjaan 
rumah yang dilakukan oleh Ibu rumah tangga juga dikategorikan dalam kegiatan olah raga sehingga merasa tidak perlu lagi untuk melakukan kegiatan olah raga yang sesungguhnya. Kesadaran dan persepsi yang kurang tepat bahwa olah raga tidak penting untuk dilakukan, olah raga hanya untuk individu yang sehat membuat penderita DM rentan dengan komplikasi.

Penderita DM yang secara fisik tidak mampu melakukan aktifitas dikarenakan faktor usia dan keterbatasan fisik misalnya karena komplikasi dan post operasi amputasi menyebabkan mereka tidak patuh akan anjuran latihan fisik. Hal ini sesuai dengan hasil penelitian yang dilakukan oleh Purba (2008) mengatakan bahwa penderita DM dengan komplikasi sering mengalami gangguan sensori persepsi seperti ketidakseimbangan glukosa insulin yang menyebabkan ketidakberdayaan, ketergantungan pada orang lain dan masa perawatan yang lama.

Hasil penelitian menunjukkan bahwa sebagian besar penderita diabetes mellitus memiliki riwayat pendidikan SD menunjukkan prosentase ketidakpatuhan yang cukup besar yaitu $46,7 \%$.

Penderita dengan tingkat pendidikan yang rendah didapatkan memiliki tingkat kepercayaan yang kurang terhadap saran pengobatan sehingga menyebabkan mereka menjadi tidak patuh dalam pengobatan. Sementara responden dengan tingkat pendidikan yang lebih tinggi memiliki tingkat pengetahuan yang lebih tentang penyakit dan pengobatannya sehingga menjadi lebih patuh (Ho et al., 2006).Pendidikan penderita dapat meningkatkan kepatuhan, sepanjang bahwa pendidikan tersebut merupakan pendidikan yang aktif.

Tingkat pendidikan penderita yang tinggi dapat menjadi perantara untuk meningkatkan pengetahuan akan pengobatan diabetes mellitus. Pengetahuan yang baik akanmenimbulkan motivasi dalam melakukan perubahan perilaku perawatan diri yang lebih baik.Perilaku kesehatan individu dipengaruhi oleh motivasi dari individu untuk berperilaku sehat dan menjaga kesehatannya (Vera, 2015).

Motivasi penderita diabetes mellitus yang baik merupakan wujud dari tanggung jawab individu terhadap penyakit yang dideritanya, yaitu sebagai penerima pelayanan kesehatan. Penderita diabetes mellitus cenderung mempunyai motivasi yang rendah dalam melakukan pengobatan.Walaupun sudah dipastikan bahwa pengobatan merupakan poin penting dalam tatalaksana diabetes mellitus namun tidak menjamin bahwa penderita diabetes mellitus tersebut mempunyai motivasi yang baik dalam melakukan pengobatan.

Motivasi dapat berasal dari dalam diri penderita karena faktor pengetahuan dan juga dapat berupa motivasi eksternal yang berasal dari orang sekitar dan lingkungan.Dalam hal ini dukungan keluarga dalam pengobatan diabetes mellitus sangat dibutuhkan oleh penderita yang notabene menjalani pengobatan jangka panjang.

Berdasarkan hasil penelitian didapatkan bahwa sebagian besar penderita diabetes mellitus adalah perempuan dengan prosentase ketidakpatuhan lebih dari $50 \%$.

Jenis kelamin berkaitan dengan peran dalam kehidupan serta perbedaan perilaku antara lakilaki dan perempuan dalam kehidupan bermasyarakat (Novian, 2013). Jenis kelamin merupakan salah satu faktor yang berhubungan dengan ketidakpatuhan klien.pria lebih patuh dalam menjalani pengobatan diabetes dibandingkan wanita (Setiawan dan Fitria, 2016).Perempuan memiliki resiko lebih tinggi untuk menderita penyakit diabetes mellitus dikarenakan beberapa faktor diantaranya adalah kelebihan berat badan (obesitas), penggunaan kontrasepsi oral, tingkat stres yang tinggi serta riwayat kehamilan (Ramadona, 2011).

Faktorprediktifuntukketidakpatuhantermasu kdiantaranya adalah penderita dengan jenis kelamin perempuan.Perempuan memiliki tingkat aktivitas yang tinggi sehingga berdampak pada kelalaian untuk minum dan menebus obat (Srikartika et al, 2016). Selain karena alasan tersebut, dijelaskan juga bahwa penderita dengan jenis kelamin laki-laki lebih memperhatikan penyakitnya. Hal tersebut membuat responden laki-laki lebih patuh dalam melakukan perawatan kesehatan diri dengan cara minum obat secara teratur, rutin melakukan olah raga dan mengatur pola diit (Romadona, 2011).

Berdasarkan keterangan diatas menunjukkan bahwa responden perempuan tidak hanya membutuhkan kemampuan finansial yang baik untuk berobat, akan tetapi dukungan berupa pemahaman akan karakter perempuan yang selalu mengutamakan kepentingan keluarganya sehingga mengabaikan penatalaksanaan kesehatannya. 
PROFESI (Profesional Islam): Media Publikasi Penelitian

2019; Volume 16; No 2.

Website: ejournal.stikespku.ac.id

Pendekatan yang tepat sangat dibutuhkan untuk responden perempuan dalam rangka meningkatkan kepatuhan. Dukungan sosial dan support keluarga terdekat khususnya pasangan hidup akan menjadi perantara yang memiliki potensial keberhasilan tinggi dalam mencapai keberhasilan pengobatan sehingga kontrol glikemik mencapai maksimal.

Pemahaman yang baikakan penatalaksanaan pengobatan diabetes mellitus sangat diperlukan untuk mencapaikontrol metabolikyang baik. Peningkatan pengetahuan dapat dilakukan dengan cara meningkatkan interaksi dengan petugas kesehatan terkait untuk mencapai kontrol kesehatan yang baik.

\section{KESIMPULAN}

Berdasarkanhasil penelitian yang dilakukan pada penderita diabetes mellitus tipe 2 di Desa Satrean Kecamatan Maron Kabupaten Probolinggo dapat disimpulkan bahwa sebagian besar penderita diabetes mellitus yang tidak patuh dalam pengobatan adalah perempuan usia dewasa akhir yang tidak bekerja dengan tingkat pendidikan SD.

Sesuai dengan hasil penelitian yang telah dilakukan maka sangat dibutuhkan penelitian yang lebih lanjut mengenai metode pendidikan kesehatan yang tepat sesuai karakteristik penderita maupun keluarga yang dapat meningkatkan pengetahuan dan pemahaman dalam hal penatalaksanaan diabetes mellitus.Peningkatan pengetahuan pada keluarga diharapkan dapat memberikan dukungan kepada penderita sehingga dapat meningkatkan kualitas hidup penderita dan mencegah terjadinya komplikasi lebih lanjut.

\section{REFERENSI}

Adikusuma, W., Perwitasari, D.A., Supadmi,W. (2014). Evaluasi Kepatuhan Pasien Diabetes Mellitus Tipe 2 di Rumah Sakit Umum PKU Muhammadiyah Bantul Yogyakarta. Media Farmasi. 11 (2): 208220

American Medical Association. (2008). American Medical Association Complete Guide to Prevention and Wellness. Wiley: United State of America.
Basuki, E. (2009). Teknik Penyuluhan Diabetes Mellitus: Penatalaksanaan Diabetes Mellitus Terpadu Edisi Ke 7. Jakarta: Balai Penerbit FKUI.

Davies, M.J., Gagliardino, J.J., Gray, L.J., Khunti, K., Mohan, V., Hugles, R. (2013). Real-world factors affecting adherence to insulin therapy in patients with Type 1 or Type 2 diabetes mellitus: a systematic review.Department of Cardiovascular Sciences, University of Leicester, UK. 10.1111/dme.12128.

Delamater, A.M. (2006). Improving Patient Adherence. Clinical Daibetes Journal. 24(2): 77177

Ho, M., Rumsfeld, J.S., Masoudi, F.A., McClure, D.L., Plomondon, M.E., Steiner, J.F., \& Magid, D.J. (2006). Effect of medication noncompliance in type 2 diabetic patients.Sahhid Publica Mex. 45: 191-19

Niven, N. (2008). Psikologi Kesehatan: Pengantar untuk Perawatan Profesional. Jakarta: EGC.

Novian, A. (2013). Faktor yang berhubungan dengan kepatuhan diit pasien hipertensi, Semarang: Skripsi. Jurusan Ilmu Kesehatan Masyarakat Fakultas Ilmu Keolahragaan Universitas Negeri Semarang

Pladevall, M., Williams, L. K., Potts, L.A., Divine, G., Xi, H., \& Lafata, J. E. (2014).Clinical Outcome and Adherence to Medications Measured by Claims Data in Patients with Diabetes. Diabetes Care. 12(27): 2800-2805.

Pratiwi, Y.B., \& Endang, N.W. (2013). Hubungan Antara Dukungan Keluarga Dengan Kepatuhan Diit Pada Pasien Diabetes Mellitus Tipe 2 Rawat Jalan Di RSUD Dr. Soediran Mangun Sumarso.Skripsi. Prodi Gizi Fakultas Ilmu Kesehatan Universitas Muhammadiyah Surakarta

Primanda, Y., Kritpracha, C., Thaniwattananon, P. (2011). Dietary Behaviors among Patients with Type 2 Diabetes Mellitus in Yogyakarta, Indonesia. Nurse Media Journal of Nursing.211-223. 
PROFESI (Profesional Islam): Media Publikasi Penelitian 2019; Volume 16; No 2.

Website: ejournal.stikespku.ac.id

Purba, I.C., Sitorus, R., Afiyanti, Y. (2008). Pengalaman Ketidakpatuhan Pasien Terhadap Penataksanaan DM: Studi Fenomenologi Dalam Konteks Askep Di RSUPN CM Jakarta. Universitas Indonesia, Depok.

Ramadona, A. (2011). Pengaruh Konseling Obat Terhadap Kepatuhan Pasien Diabetes Mellitus Tipe 2 Di Poliklinik Khusus Rumah Sakit Umum Pusat dr. M. Djamil Padang. Tesis. Padang: Universitas Andalas.

Setiawan,A. W dan Fitria, A. N.(2016). Diabetes Melitus Dengan Insomnia Ditinjau Dari Karakteristik Pasien Di Puskesmas BaloWerti Kediri. Jurnal Keperawatan Bina Sehat. 9 (2).
Srikartika, V. M., Dwi, A. C., Suci, R. W. (2016). Analisis Faktor Yang Memengaruhi Kepatuhan Penggunaan Obat Pasien Diabetes Melitus Tipe 2. Jurnal Manajemen dan Pelayanan Farmasi. Universitas Lambung Mangkurat, Kalimantan Selatan. 6 (3)

Vera T., Rattu A. J. M., Tilaar Ch. R. (2015). Faktor-faktor yang Berhubungan dengan Kepatuhan Berobat Pasien Diabetes Melitus pada Praktek Dokter Keluarga di Kota Tomohon. JIKMU. 5( 2) Tombokan, Rattu dan Tilaar.

WHO. (2006). Definition and diagnosis of diabetes mellitus and intermediate hyperglycemia. Switzerland: WHO. 